\title{
Pengaruh Model Pembelajaran Discovery Inquiry Berbasis Portofolio Terhadap Kompetensi Pengetahuan IPA
}

\author{
Ni Kadek Nova Restyani' ${ }^{1}$ Komang Ngurah Wiyasa², I.B Gede Surya Abadi ${ }^{3}$ \\ 1 Jurusan PGSD Universitas Pendidikan Ganesha Singaraja, Indonesia \\ 2 Jurusan PGSD Universitas Pendidikan Ganesha Singaraja, Indonesia \\ 3 Jurusan PGSD Universitas Pendidikan Ganesha Singaraja, Indonesia
}

\begin{abstract}
Abstrak
Penelitian ini bertujuan untuk mengetahui pengaruh model pembelajaran Discovery Inquiry berbasis potofolio terhadap kompetensi pengetahuan IPA antara kelompok siswa yang dibelajarkan menggunakan model pembelajaran Discovery Inquiry berbasis porotofolio dan kelompok siswa yang dibelajarkan dengan menggunakan pembelajaran konvensional pada siswa kelas V SD Gugus Dewi Sartika Denpasar Selatan tahun ajaran 2017/2018. Jenis penelitian ini merupakan eksperimen semu dengan desain penelitian non-equivalent control group design. Populasi penelitian adalah seluruh siswa kelas V SD Negeri di Gugus Dewi Sartika yang terdiri dari 7 kelas $\mathrm{V}$ dengan jumlah siswa sebanyak 271 siswa. Sampel ditentukan dengan teknik random sampling. Sampel penelitian ini adalah siswa kelas VA SDN 13 Pedungan sebagai kelompok eksperimen dan siswa kelas V SDN 3 Pedungan sebagai kelompok kontrol. Hasil analisis menunjukan terdapat perbedaan yang signifikan kompetensi pengetahuan IPA kelompok yang dibelajarkan dengan model pembelajaran Discovery Inquiry berbasis portofolio dan kelompok siswa yang dibelajarkan dengan pembelajaran konvensional pada siswa kelas V SD Gugus Dewi Sartika Denpasar Selatan tahun ajaran $2017 / 2018$. Hal tersebut dibuktikan dengan hasil thitung 5,405 dan pada taraf signifikansi $5 \%(=0,05)$ dengan $\mathrm{dk}=(26+44)-2=68$ diperoleh ttabel 2,000 . Berdasarkan kriteria pengujian thitung $=5,405>$ ttabel $(=0,05)=2,000$. Nilai rerata penguasaan kompetensi pengetahuan IPA siswa kelompok eksperimen X1= $0,60>\mathrm{X} 2=0,40$ rerata penguasaan kompetensi pengetahuan IPA kelompok kontrol. Dengan demikian dapat disimpulkan bahwa model pembelajaran Discovery Inquiry berbasis portofolio berpengaruh terhadap penguasaan kompetensi pengetahuan IPA siswa kelas V di SD Gugus Dewi Sartika Denpasar Selatan, dan model pembelajaran Discovery Inquiry berbasis portofolio dapat digunakan dalam pembelajaran IPA sehingga tercipta pembelajaran yang bermakna.
\end{abstract}

\author{
Keywords: \\ discovery inquiry, \\ portofolio, kompetensi \\ pengetahuan IPA.
}

\section{PENDAHULUAN}

Sistem pendidikan nasional di era globalisasi seperti saat ini menghadapi tantangan yang sangat kompleks dalam menyiapkan kualitas sumber daya manusia (SDM) yang mampu bersaing. Upaya yang tepat untuk menyiapkan SDM yang berkualitas dan satu-satunya wadah yang dipandang dan seyogyanya berfungsi sebagai alat untuk membangun SDM yang bermutu tinggi adalah pendidikan. Sistem pendidikan yang baik diharapkan akan dapat memunculkan generasi penerus bangsa yang berkualitas dan mampu menyesuaikan diri untuk hidup bermasyarat, berbangsa dan bernegara. Hal ini menjadi respon terhadap perkembangan tuntutan global sebagai suatu upaya untuk mengadaptasi sistem pendidikan yang mampu mengembangkan sumber daya manusia guna memenuhi tuntutan zaman yang sedang berkembang.

Penerapan kurikulum merupakan salah satu hal yang sedang dihadapi oleh Indonesia. Kurikulum yang sering berubah-ubah dianggap kurang efektif dalam pelaksanaan proses pembelajaran pada kurikulum tersebut. Untuk setiap perubahan kurikulum diperlukan waktunya banyak untuk setiap penerapannya. Hal ini dapat kita lihat dari penerapan setiap kurikulum selalu diawali dengan adanya sosialisasi kurikulum, pelatihan, hingga pemahaman oleh guru dan siswa yang tentunya memerlukan

\footnotetext{
* Corresponding author.

E-mail Addresses: - nova.retyani@undiksha.ac.id (Ni Kadek Nova Restyani), ngrh.wiyasa@undiksha.ac.id (Komang Ngurah Wiyasa) idabagusgedesurya.abadi@undiksha.ac.id (I. B. Gede Surya Abadi)
} 
waktu yang cukup lama hingga pelaksanaan kurikulum dapat dilaksanakan sesuai dengan tujuan dalam penerapannya.

Permasalahan selanjutnya yaitu masih rendahnya prestasi pendidikan di Indonesia yang dikarenakan oleh sistem pembelajaran di sekolah yang kurang efektif dan sumber daya manusia yang masih rendah. Hal ini dapat dibuktikan dari output pendidikan yang dihasilkan. Hal tersebut dilihat dari siswa yang kurang aktif dan belum mampu mengkonstruksi pengetahuannya. Siswa lebih banyak menghafal pembelajaran daripada menalar, selain itu siswa kurang meggali infomasi melalui membaca atau sumber lainnya, hanya mengandalkan informasi yang diberikan oleh guru dan menganggap guru adalah pusat informasi satu-satunya.

Di Bali khususnya permasalahan tersebut adalah hal yang sering dihadapi di dalam lingkungan sekolah. Di Bali belum sepenuhnya melaksanakan kurikulum yang telah ditetapkan yakni kurikulum 2013. Kemudian, banyaknya siswa yang mengalami putus sekolah dilator belakangi oleh banyak faktor, salah satunya faktor ekonomi. Bagi masarakat Bali biaya pendidikan terbilang cukup mahal yang mengakibatkan mutu pendidikan kurang menjadi perhatian bagi orang tua. Dan siswa yang mengalami pengulangan dapat diakibatkan oleh proses pembelajaran yang dilakukan dimana siswa lebih banyak menghafal pembelajaran daripada memahami konsep pembelajaran tersebut serta mengkonstruksikan pengetahuannya khususnya di bidang Ilmu Pengetahuan Alam (IPA). Kemudian sarana dan prasarana yang disediakan oleh pemerintah di setiap kabupaten atau kota berbeda yang dikarenakan oleh pendapatan daerah di masing-masing kabupaten atau kota madya tentu berbeda. Kurangnya sarana dan pra sarana di sekolah dapat mengakibatkan kurang optimalnya informasi yang diperoleh siswa.

Berdasarkan hasil observasi yang dilakukan pada tanggal 10 Januari 2018 dengan semua guru kelas V SD Gugus Dewi Sartika Denpasar Selatan, untuk kompetensi pengetahuan IPA diperoleh dari hasil rapot dari semester I, Kriteria ketuntasan minimal (KKM) yang ditetapkan sekolah untuk mata pelajaran IPA adalah 70. 10 siswa mendapat nilai A, 43 siswa mendapat nilai B, 157 siswa mendapat nilai C, dan 61 siswa mendapat nilai D. Berdasarkan data yang diperoleh 53 siswa atau 19,56\% yang sudah mencapai nilai yang diharapkan. Sedangkan 218 siswa atau 80,44\% belum mampu menunjukan kompetensi pengetahuan yang baik. Maka untuk itu diperlukan model pembelajaran yang dapat mendukung siswa untuk lebih aktif dalam mencari dan menemukan suatu permasalahan sehingga siswa lebih berfikir secara kritis. Kemungkinan tersebut dapat memengaruhi pemahaman siswa terhadap kompetensi pengetahuan IPA secara khususnya.

Melihat hal tersebut, salah satu model pembelajaran yang dapat memengaruhi kompetensi IPA siswa lebih baik yaitu model pembelajaran discovery inquiry. (Wisudawati\&Sulistyowati,2014:80) Model pembelajaran Discovery-Inquiry merupakan model pembelajaran esensial dalam melaksanakan proses pembelajaran IPA. Model pembelajaran Discovery-Inquiry merupakan pembelajaran yang berpusat pada peserta didik. Pembelajaran discovery merupakan pembelajaran yang selalu melibatkan peserta didik dalam pembangunan konsep IPA yang melibatkan proses mental yang terjadi di dalam diri peserta didik. (Wisudawati\&Sulistyowati,2014:81) menyatakan proses mental yang terjadi ketika menggunakan model pembelajaran discovery adalah observasi, klasifikasi, pengukuran, prediksi, penentuan dan inferi. Proses mental dalam discovery merupakan bagian dari inkuiri. Dalam pelaksanaan model pembelajaran ini, peserta didik diminta untuk mencari tahu tentang objek IPA melalui pertanyaan-pertanyaaan logis-kritis. Model pembelajaran ini memiliki keunggulan yang diyakini dapat memengaruhi kompetensi pengetahuan, khususnya IPA.

Untuk mempermudah guru dalam mengembangkan penerapan kurikulum 2013, model pembelajaran discovery inquiry ini menggunakan asesmen otentik. Asesmen otentik yang digunakan salah satunya adalah asesmen portofolio. Dari beberapa bentuk penilaian proses yang telah disebutkan, maka portofolio dianggap dapat meningkatkan kualitas proses pembelajaran dan sekaligus hasil belajar. (Sukmasari,2015:vol3) asesmen portofolio adalah penilaian atas sekumpulan artefak (bukti/karya/kegiatan/data) sebagai bukti (evidence) yang menunjukan perkembangan dan pencapaian suatu program. (Anita Yus,2006:69) portofolio adalah kumpulan hasil karya peserta didik yang disusun secara sistematik yang menunjukan dan membuktikan upaya belajar, hasil belajar, proses belajar dan kemanjuan (progress) yang dilakukan peserta didik dalam jangka waktu tertentu. Atas dasar itulah, portofolio sangat tepat diterapkan dalam model pembelajaran Discovery Inquiry.

Dari uraian di atas, untuk mengetahui seberapa jauh terdapat perbedaan dari pengaruh penggunaan model pembelajaran discovery-inquiry berbasis portofolio terhadap penguasaan kompetensi pengetahuan IPA. Pada penelitian ini, peneliti perlu mengadakan penelitian yang berjudul "Pengaruh Model Pembelajaran Discovery-Inquiry Berbasis Portofolio Terhadap Kompetensi Pengetahuan IPA Siswa Kelas V SD Gugus Dewi Sartika Denpasar Selatan Tahun Pelajaran 2017/2018. 


\section{METODE PENELITIAN}

Penelitian ini dilaksanakan di Sekolah Dasar Negeri yang terdapat di Gugus Dewi Sartika Kecamatan Denpasar Selatan. Penelitian ini pada dasarnya bertujuan untuk mengetahui pengaruh model pembelajaran discovery inquiry berbasis portofolio terhadap kompetensi pengetahuan IPA kelas V SD Gugus Dewi Sartika Denpasar Selatan tahun ajaran 2017/2018.

Jenis penelitian yang dilaksanakan ini merupakan penelitian eksperimen semu (quasi eksperimental design) yang memiliki kelompok kontrol, tetapi tidak dapat berfungsi sepenuhnya untuk mengontrol variabel-variabel luar yang mempengaruhi pelaksanaan eksperimen (Sugiyono, 2016:114). Pada penelitian ini, pre-test diberikan untuk kelompok kontrol dan kelompok eksperimen untuk mengetahui kesetaraan antara kelompok satu dengan yang lainnya. Hal tersebut didukung oleh pendapat Dantes (2012: 97) yang menyatakan bahwa pemberian pre-test biasanya untuk mengukur ekuivalensi atau penyetaraan kelompok. Bentuk desain kuasi eksperimen yang digunakan adalah rancangan kelompok non- ekuivalen sebagai berikut.

\begin{tabular}{|lrrl|}
\hline O1 & X & O2 & (Eksperimen) \\
\hdashline O3 & & O4 & (Kontrol) \\
\hline
\end{tabular}

Gambar 1. Desain Eksperimen Rancangan Kelompok Non-ekuivalen

Dalam suatu penelitian tidak lepas dari objek yang diteliti, seperti halnya penelitian eksperimen ini tentang pengaruh model pembelajaran discovery inquiry berbasis portofolio terhadap kompetensi pengetahuan IPA kelas V SD Gugus Dewi Sartika Denpasar Selatan tahun ajaran 2017/2018. Subjek yang diteliti diistilahkan sebagai populasi dan sampel. Populasi merupakan keseluruhan dari objek, orang, peristiwa, atau sejenisnya yang menjadi perhatian dan kajian dalam penelitian (Setyosari, 2015:221). Sedangkan menurut Sugiyono (2016:117) menyatakan, populasi adalah wilayah generalisasi yang terdiri atas: objek/subjek yang mempunyai kualitas dan karakteristik tertentu yang ditetapkan oleh peneliti untuk dipelajari dan kemudian ditarik kesimpulan (Sugiyono 2016:117). Populasi penelitian ini adalah seluruh siswa kelas V di SD Gugus Dewi sartika Denpasar Selatan yang terdiri dari 4 sekolah negeri yaitu SDN 3 Pedungan, SDN 6 Pedungan, SDN 11 Pedungan, SDN 13 Pedungan dengan jumlah siswa 271 orang.

Dalam penelitian, populasi tidak terlepas dari adanya sampel dikarenakan sampel merupakan bagian dari populasi. Setelah mengetahui populasi, langkah selanjutnya adalah menentukan sampel penelitian. Menurut Agung, (2014:69), sampel adalah sebagian dari populasi yang diambil, yang dianggap mewakili seluruh populasi dan diambil dengan menggunakan teknik tertentu. Sedangkan menurut Setyosari (2015:221), mengatakan sampel merupakan sejumlah kelompok kecil yang mewakili populasi untuk dijadikan sebagai objek penelitian.

Penentuan sampel menggunakan teknik Random Sampling yang dirandom kelasnya, sehingga setiap kelas mendapatkan peluang yang sama untuk menjadi sampel penelitian. Pemilihan sampel penelitian ini tidak dilakukannya pengacakan individu melainkan hanya pengacakan kelas. Karena tidak bisa mengubah kelas yang telah terbentuk sebelumnya. Kelas dipilih sebagaimana telah terbentuk tanpa campur tangan peneliti dan tidak dilakukannya pengacakan individu, kemungkinan pengaruh-pengaruh dari keadaan siswa mengetahui dirinya dilibatkan dalam eksperimen dapat dikurangi sehingga penelitian ini benar-benar menggambarkan pengaruh perlakuan yang diberikan.

Cara yang digunakan untuk mendapatkan sampel adalah dengan cara pengundian. Cara undian dilakukan dengan menulis semua nama kelas $V$ di seluruh SDN populasi pada masing-masing kertas yang jumlahnya 7 kelas, kemudian kertas digulung. Gulungan kertas dimasukkan ke dalam kotak dan diundi. Ambil dua gulungan kertas. Nama-nama SDN pada kedua gulungan kertas tersebut merupakan sampel penelitian. Setelah mendapatkan 2 kelas sebagai sampel dengan menggunakan teknik random sampling, maka kelas tersebut diberikan pre test. Nilai atau skor dari hasil pre test yang dilakukan tersebut, digunakan untuk penyetaraan kelas sampel. Untuk penyetaraan kelas, nilai atau skor dari hasil pre test dianalisis menggunakan uji t. Sebelum uji kesetaraan menggunakan uji t, maka data hasil pre test diuji prasyarat yaitu uji normalitas dan homogenitasnya. Jika data pre test yang diperoleh sudah memenuhi prasyarat uji normalitas dan homogenitas maka dianalisis menggunakan uj-t yakni dengan polled varian.

Data yang dianalisi dalam penelitian ini adalah data kompetensi pengetahuan IPA. Kegiatan pengumpulan data ini dilakukan pada siswa kelas V SD Gugus Dewi Sartika Denpasar Selatan Tahun Ajaran 2017/2018. Metode pengumpulan data dapat dikumpulkan melalui metode tes dan non tes. Dalam 
penelitian ini, metode pengumpulan data yang digunakan adalah metode tes. Metode tes dalam kaitannya dengan penelitian menurut Agung (2012:66) adalah cara memperoleh data yang berbentuk suatu tugas yang dilakukan atau dikerjakan oleh seseorang atau sekelompok orang yang di tes dan dari hasil tes tersebut dapat menghasilkan suatu data berupa skor. Arikunto (2015:67) Tes adalah "alat atau prosedur yang digunakan untuk mengetahui atau mengukur sesuatu dalam suasana, dengan cara dan aturan-aturan yang sudah ditentukan". Instrumen yang digunakan untuk pengumpulan data penguasaan kompetensi pengetahuan IPA adalah tes. Jenis tes yang digunakan yaitu tes objektif pilihan ganda biasa, yaitu terdiri atas suatu keterangan atau pemberitahuan tentang suatu pengertian yang belum lengkap. Untuk melengkapinya harus memilih satu dari beberapa kemungkinan jawaban yang telah disediakan. Kemungkinan jawaban terdiri atas satu jawaban yang benar yaitu kunci jawaban dan beberapa jawaban pengecoh (Suharsimi, 2015:183).

Pada penelitian ini menggunakan 2 variabel, variabel bebas (independent) dan variabel terikat (dependent). Variabel bebas pada penelitian ini adalah model pembelajaran discovery inquiry berbasis portofolio sedangkan variabel terikat pada penelitian ini adalah penguasaan kompetensi pengetahuan IPA. Analisis data deskriptif merupakan analisis yang dipakai untuk menganalisis data dengan mendeskripsikan atau menggambarkan data - data yang sudah dikumpul. Statistik inferensial adalah teknik statistik yang digunakan untuk menganalisis data sampel dan hasilnya diberlakukan untuk populasi (Sugiyono,2016:209). Pada penelitian ini, terlebih dahulu dilakukan uji prasyarat analisis sebelum uji hipotesis dianalisis dengan Kolmogorov-Smirnov. Jika data yang diperoleh sudah memenuhi prasyarat uji normalitas dan homogenitas maka analisis yang digunakan adalah statistik parametrik. Analisis statistik yang digunakan untuk menguji hipotesis penelitian ini adalah uji beda mean (uji $t$ ). Uji Hipotesis menggunakan uji-t dengan rumus polled varians. Rumus uji-t dengan rumus polled varians digunakan bila jumlah anggota sampel sama $\mathrm{n} 1=\mathrm{n} 2$ dan varians homogen.

\section{ANALISIS DAN PEMBAHASAN}

Hipotesis penelitian yang diuji dalam penelitian ini adalah hipotesis nol $\left(\mathrm{H}_{0}\right)$ yaitu tidak terdapat pengaruh yang signifikan kompetensi pengetahuan IPA antara kelompok siswa yang dibelajarkan melalui model pembelajaran discovery inquiry berbasis portofolio dan kelompok siswa yang dibelajarkan melalui pembelajaran konvensional pada siswa kelas V di SD Gugus Dewi Sartika Denpasar Selatan tahun ajaran 2017/2018. Sedangkan hipotesis alternative $\left(\mathrm{H}_{\mathrm{a}}\right)$ yaitu terdapat pengaruh yang signifikan kompetensi pengetahuan IPA antara kelompok siswa yang dibelajarkan melalui model pembelajaran discovery inquiry berbasis portofolio dan kelompok siswa yang dibelajarkan melalui pembelajaran konvensional pada siswa kelas V di SD Gugus Dewi Sartika Denpasar Selatan tahun ajaran 2017/2018.

Hasil perhitungan menunjukkan nilai rata-rata kompetensi pengetahuan IPA siswa kelompok

eksperimen yang dibelajarkan melalui model pembelajaran discovery inquiry $\bar{X}=0,60$ dengan varians $=$ 0,2 dan standar deviasi $=0,16$.

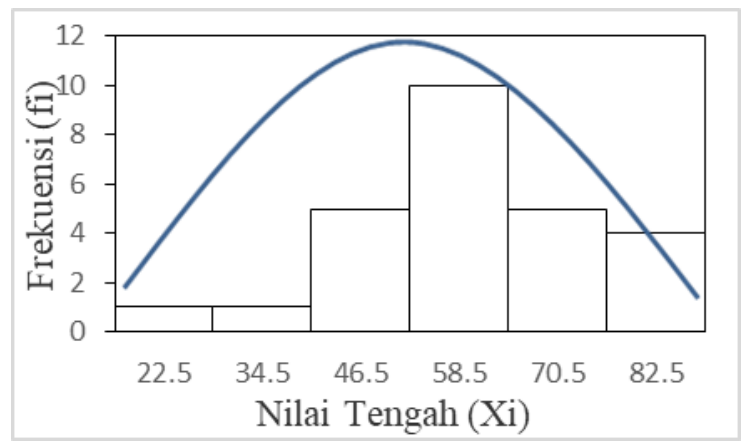

Gambar 2. Histogram Data GSn Kompetensi Pengetahuan IPA Kelompok Eksperimen

Sedangkan nilai rata-rata kompetensi pengetahuan IPA siswa kelompok kontrol yang dibelajarkan melalui pembelajaran konvensional adalah $\bar{X}=0,40$ dengan varians $=0,2$ dan standar deviasi $=0,15$. 


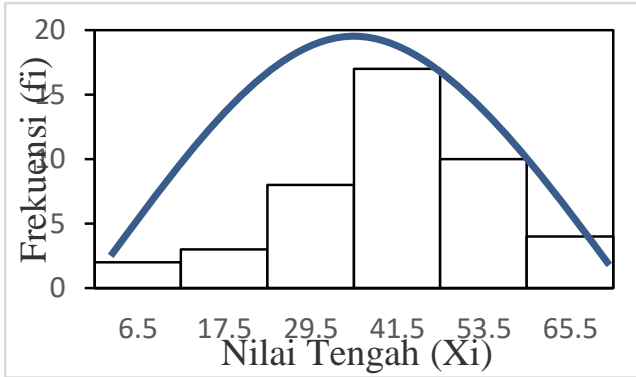

Gambar 3. Histogram Data GSn Kompetensi Pengetahuan IPA Kelompok Kontrol

Rata-rata yang diperoleh siswa kelompok eksperimen yang dibelajarakan melalui model pembelajaran discovery inquiry berbasis portofolio lebih tinggi dari nilai rata-rata yang diperoleh siswa kelompok kontrol yang dibelajarkan melalui pembelajaran konvensional. dengan uji-t, terlebih dahulu dilakukan uji prasyarat yang meliputi uji normalitas sebaran data kelompok eksperimen dan kelompok kontrol.

Berdasarkan atas kurve normal, kelas interval, frekuensi observasi $\left(f_{0}\right)$ dan frekuensi empirik $\left(f_{e}\right)$ dari data kompetensi pengetahuan IPA siswa kelompok eksperimen diperoleh $\chi_{\text {hitung }}^{2}=0,067$ dan taraf signifikansi $\quad 5 \%$ sehingga diperoleh nilai $\chi_{\text {tabel }}^{2}=0,259$, karena $\chi_{\text {hitung }}^{2}<\chi_{\text {tabel }}^{2}(0,067<0,259)$ maka $\mathrm{H}_{0}$ diterima dan Ha ditolak. Ini berarti sebaran data nilai kompetensi pengetahuan IPA kelompok eksperimen berdistribusi normal. Sedangkan untuk kompetensi pengetahuan IPA kelompok kontrol diperolah $\chi_{\text {hitung }}^{2}=0,088$ dengan taraf signifikansi $5 \%$ sehingga diperoleh nilai $\chi_{\text {tabel }}^{2}=0,205$, karena $\chi_{\text {hitung }}^{2}<\chi_{\text {tabel }}^{2}(0,088<0,205)$ maka $\mathrm{H}_{0}$ diterima dan Ha ditolak. Ini berarti sebaran data nilai kompetensi pengetahuan IPA kelompok kontrol berdistribusi normal.

Selanjutnya dilakukan uji homogenitas varians untuk membuktikan perbedaan yang terjadi pada kedua kelompok benar-benar terjadi akibat adanya perbedaan antar kelompok, bukan sebagai akibat adanya perbedaan individu dalam kelompok. Berdasarkan tabel nilai-nilai distribusi F diperoleh sebesar Ftabel 1,76. Berdasarkan hasil penghitungan diperoleh harga Fhitung kurang dari Ftabel $(1<1,76)$ maka H0 diterima. Ini berarti varians data kompetensi pengetahuan IPA antara kelompok eksperimen dan kelompok kontrol adalah homogen.

Berdasarkan hasil uji prasyarat yaitu uji normalitas sebaran data dan uji homogenitas varians, dapat diketahui bahwa data tersebut berdistribusi normal dan mempunyai varians yang homogen. Oleh karena itu, untuk uji hipotesis dilakukan dengan menggunakan statistik yakni uji-t dengan rumus polled varians. Hal tersebut dikarenakan kelompok eksperimen dan kelompok kontrol memiliki jumlah sampel yang berbeda dan varians yang homogen. Berikut disajikan rekapitulasi hasil analisis data dengan menggunakan uji-t. Pada Tabel 1.

Tabel 1. Rekapitulasi Analisis Uji-t

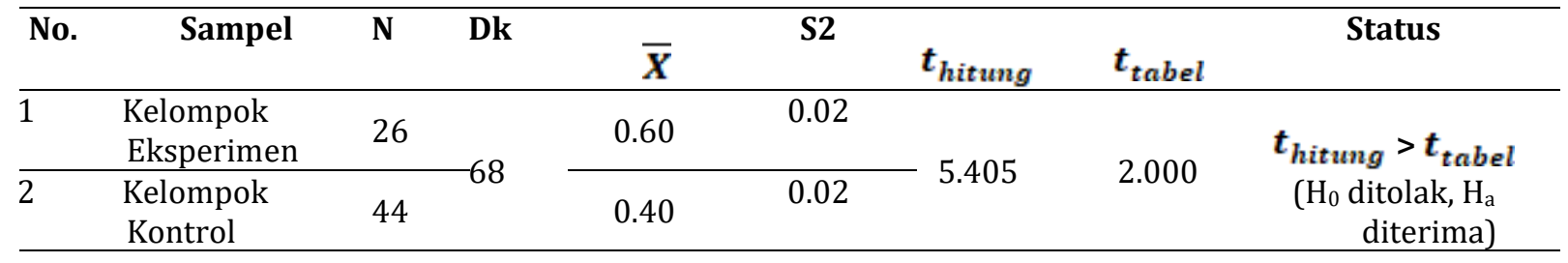

Berdasarkan hasil analisis data diperoleh $t_{\text {hitung }}=5,405$ dengan menggunakan taraf signifikansi $5 \%$ dan derajat kebebasan $(\mathrm{dk})=26+44-2=68$ diperoleh batas penolakan hipotesis nol $t_{\text {tabel }}=2,000$. Hal ini berarti $t_{\text {hitung }}>t_{\text {tabel }}(5,405>2,000)$ maka hipotesis nol yang diajukan ditolak dan menerima hipotesis alternatif. Maka dapat diinterpretasikan bahwa terdapat pengaruh yang signifikan kompetensi 
pengetahuan IPA antara siswa yang dibelajarkan dengan model pembelajaran discovery inquiry berbasis portofolio dengan siswa yang dibelajarkan dengan pembelajaran konvensional.

Dengan diterapkannya model pembelajaran discovery inquiry berbasis porotofolio pada siswa kelompok eksperimen dan pembelajaran konvensional pada kelompok kontrol, tentunya untuk mengetahui pengaruh kompetensi pengetahuan dari penerapan pendekatan tersebut. Setelah kelompok eksperimen dan kelompok kontrol diberikan perlakuan, maka kedua kelas tersebut diberikan post test untuk mencari kompetensi pengetahuan IPA. Adapun hasil analisis data penelitian pada kedua kelas

diperoleh bahwa rerata kompetensi pengetahuan IPA pada kelompok eksperimen adalah $\bar{X}=0,60$ dan kelompok kontrol adalah $\bar{X}=0,40$. Selanjutnya data kompetensi pengetahuan IPA diuji menggunakan

statistik uji-t dan diperoleh $t_{\text {hitung }}=5,405>t_{\text {tabel }}=2,000$. Hal ini berarti hipotesis alternatif yang menyatakan bahwa terdapat pengaruh yang signifikan kompetensi pengetahuan IPA antara siswa yang dibelajarkan dengan model pembelajaran discovery inquiry berbasis portofolio dengan siswa yang dibelajarkan dengan pembelajaran konvensional dengan taraf signifikansi 5\% diterima. Hal tersebut didukung juga adanya perbedaan nilai rerata kompetensi pengetahuan IPA antara kelompok eksperimen

yaitu $\bar{X}=0,60$ dan $\bar{X}=0,40$ pada kelompok kontrol. Hal ini memnunjukan kompetensi pengetahuan siswa pada kelompok eksperimen lebih baik apabila dibandingkan dengan kompetensi pengetahuan siswa pada kelompok kontrol. Hal ini dikarenakan model pembelajaran discovery inquiry berbasis portofolio dapat menarik minat siswa dan memotivasi siswa belajar lebih aktif.

Dengan demikian, model pembelajaran discovery inquiry berbasis portofolio dapat direkomendasikan dalam membelajarkan siswa khususnya pada kegiatan pembelajaran yang berisi muatan materi IPA selain model pembelajaran konvensional. Kegiatan pembelajaran menggunakan model pembelajaran discovery inquiry dengan model pembelajaran konvensional memberikan hasil kompetensi yang berbeda pada siswa karena baik model pembelajaran berbasis portofolio maupun model pembelajaran konvensional berpusat pada siswa serta berbasis pada pendekatan saintifik sebagai ciri khas dalam kegiatan pembelajaran Kurikulum 2013, hanya saja langkah-langkah pada kegiatan pembelajarannya yang berbeda. Selain itu, masing-masing model tersebut memiliki kelebihan dalam membelajarkan siswa. Model pembelajaran discovery inquiry adalah taktik yang dapat digunakan untuk mengajarkan pembelajaran yang lebih bermakna. Taktik ini bertujuan untuk mempersiapkan siswa secara cepat dengan menggunakan pengetahuannya sendiri dalam menemukan informasi yang lebih bermakna. Pembelajaran discovery merupakan pembelajaran yang selalu melibatkan peserta didik dalam pembangunan konsep IPA yang melibatkan proses mental yang terjadi di dalam diri peserta didik. Dengan pembelajaran inkuiri siswa dibimbing melakukan kegiatan dengan memberi pertanyaan awal dan mengarahkan pada suatu diskusi. Model pembelajaran discovery inquiry adalah belajar mencari dan menemukan sendiri. Sistem pengajaran yang yang menyajikan bahan pelajaran tidak dalam bentuk final, tetapi peserta didik diberi peluang untuk mencari dan menemukannya sendiri dengan mempergunakan teknik pendekatan masalah.

. Model pembelajaran ini dapat digabungkan dengan berbagai penilaian seperti portofolio. pembelajaran portofolio dapat digunakan sebagai salah satu alat penilaian diantara alat-alat penilaian yang selama ini selalu digunakan guru. Selain menilai hasil juga dilakukan penilaian proses, yaitu dengan penilaian portofolio. portofolio tidak hanya merupakan tempat penyimpanan hasil pekerjaan peserta didik tetatpi merupakan sumber informasi untuk guru dan peserta didik.Menggabungkan model pembelajaran dengan media tersebut akan semakin menambah ketertarikan siswa untuk belajar. Maka dengan diterapkannya model pembelajaran discovery inquiry berbasis portofolio berpengaruh positif terhadap kompetensi pengetahuan siswa. Hasil penelitian ini memperkuat penelitian dilakukan oleh peneliti Putri (2013) yang menemukan terdapat perbedaan hasil belajar IPA yang signifikan antara kelompok siswa yang mengikuti pembelajaran dengan pendekatan inkuiri terbimbing dan kelompok siswa yang mengikuti pembelajaran dengan pendekatan ekspositori ( $\mathrm{t}$ hitung $=8,69>\mathrm{t}$ tabel $=1,671$ ). dan penelitian yang dilakukan oleh Dewi (2015) yang menemukan terdapat perbedaan yang signifikan hasil belajar IPA antara kelompok siswa yang belajar menggunakan pendekatan kontekstual berbantuan asesmen portofolio dengan kelompok siswa yang belajar menggunakan model pembelajaran konvensional (thitung 8,801 > ttabel 2,00). Berdasarkan pemaparan tersebut, dapat disimpulkan bahwa penerapan model pembelajaran discovery inquiry berbasis portofolio terdapat pengaruh yang signifikan terhadap kompetensi pengetahuan IPA siswa kelas V SD Gugus Dewi sartika Denpasar Selatan Tahun Ajaran 2017/2018. 


\section{KESIMPULAN}

Berdasarkan hasil penelitian dan pembahasan, dapat disimpulkan sebagai berikut. Berdasarkan hasil analisis data post test nilai rata-rata kompetensi pengetahuan IPA kelompok eksperimen yaitu ${ }^{-} \mathrm{X}=$ 0,60 Jadi, dapat disimpulkan bahwa model pembelajaran discovery inquiry berbasis portofolio memperoleh kompetensi pengetahuan IPA yang sangat baik.

Berdasarkan hasil analisis data post test nilai rata-rata kompetensi pengetahuan IPA kelompok kontrol yaitu ${ }^{-} \mathrm{X}=0,40$. Jadi, dapat disimpulkan bahwa pembelajaran konvensional memperoleh kompetensi pengetahuan IPA yang baik.

Hasil penelitian analisis data post test menunjukkan bahwa rerata kompetensi pengetahuan IPA kelompok eksperimen lebih tinggi daripada rerata kelompok kontrol $(0,60>0,40)$. Berdasarkan hasil analisis uji-t diperoleh t_hitung sebesar 5,405 dan t_tabel dengan $\mathrm{dk}=26+44-2=68$ pada taraf signifikansi 5\% adalah 2,000 karena t_hitung > t_tabel $(5,405>2,000)$, maka H0 ditolak. Hal ini membuktikan bahwa terdapat pengaruh yang signifikan kompetensi pengetahuan IPA kelompok siswa yang dibelajarakan melalui model pembelajaran discovery inquiry berbasis portofolio dengan siswa yang dibelajarkan melalui pembelajaran konvensional.

Jadi dapat disimpulkan bahwa penerapan model pembelajaran discovery inquiry berbasis portofolio terdapat pengaruh yang signifikan kompetensi pengetahuan IPA kelompok siswa yang dibelajarakan melalui model pembelajaran discovery inquiry berbasis portofolio dengan siswa yang dibelajarkan melalui pembelajaran konvensional pada siswa kelas V SD Gugus Dewi Sartiks Denpasar Selatan Tahun Ajaran 2017/2018 sehingga model pembelajaran discovery inquiry berbasis portofolio berpengaruh terhadap kompetensi pengetahuan IPA siswa.

Berdasarkan hasil penelitian ini, maka saran yang dapat diajukan adalah sebagai berikut. 1) Kepada Guru, dengan adanya penelitian ini guru hendaknya dapat menambah wawasannya mengenai inovasi pembelajaran sehingga mampu menerapkan pembelajaran di kelas secara lebih inovatif dan bervariasi agar dapat memberikan dampak positif dalam meningkatkan kompetensi pengetahuan siswa., 2) Kepada Kepala Sekolah, hasil penelitian ini dapat dijadikan pedoman kepada kepala sekolah untuk menciptakan kondisi yang mampu memotivasi dan meningkatkan kualitas guru-guru dalam merancang pembelajaran yang inovatif dalam membelajarkan siswa sesuai dengan yang diharapkan dalam kurikulum 2013, sehingga dapat meningkatkan mutu dan kualitas sekolah menjadi lebih unggul dan inovatif dapat berkontribusi penuh dalam meningkatkan kualitas serta mengoptimalkan proses pembelajaran, sehingga berdampak positif pada kompetensi pengetahuan siswa khususnya di sekolah dasar, 3) Kepada Peneliti Lain, dengan adanya penelitian ini diharapkan peneliti lain agar dapat mengembangkan berbagai model pembelajaran lain pada subjek penelitian yang berbeda sehingga proses pembelajaran IPA dapat berlangsung optimal dan memberikan dampak positif bagi kompetensi pengetahuan IPA siswa..

\section{DAFTAR PUSTAKA}

Agung, Gede. 2014. Metodelogi Pendidikan. Yogyakarta: Aditya Media Publishing.

Agung, Gede. 2016. Statistika Dasar Untuk Pendidikan. Yogyakarta: Budi Utama

Al-Tabany, Badar. 2014. Mendesain Model Pembelajaran Inovatif, Progresif, dan Kontekstual. Jakarta: Prenamedia Group

Arikunto, Suharsimi. 2015. Dasar -Dasar Evaluasi Pendidikan. Jakarta: Bumi Aksara.

Hanafiah dan Suhana. 2009. Konsep Strategi Pembelajaran. Bandung: PT. Refika Aditama

Harmianto. 2015. Model-Model Pembelajaran Inovatif. Bandung: Alfabeta

Kosasih. 2014. Strategi Belajar dan Pembelajaran. Bandung: Yrama Widya

Parwati, Ni Wayan Reni, dkk. 2015. "Pengaruh Model Pembelajaran Starter Eksperimen Berbasis Penilaian Portofolio Terhadap Hasil Belajar IPA Siswa Kelas IV Gugus VIII Kecamatan Abang”. EJournal PGSD Universitas Pendidikan Ganesha, Volume 1, Nomor 1.

Sani, Abdullah. 2014. Pembelajaran Saintifik Untuk Implementasi Kurikulum 2013. Jakarta: Bumi Aksara 
Sanjaya,Wina. 2005. Pembelajaran Dalam Implementasi Kurikulum Berbasis Kompetensi. Jakarta: Kencana Media Group

Setyosari. 2013. Metode Penelitian Pendidikan dan Pengembangan. Jakarta: Prenada Media Group

Sudiana, I Wauan, dkk. 2013. "Pengaruh Model Pembelajaran Inquiry Terbimbing Terhadap Hasil Belajar Matematika Siswa kelas III SD Gugus 1 Kecamatan Buleleng". E-Journal PGSD Universitas Pendidikan Ganesha, Volume 1, Nomor 1.

Sugiyono. 2012. Metode Penelitian Pendidikan (Pendekatan Kuantitatif, Kualitatif dan R\&D). Bandung: Alfabeta

Suksmasari, Ni Nyoman, dkk. 2015. "Pengaruh Pendekatan Saintifik Berbasis Asesmen Portofolio Terhadap Hasil Belajar Keterampilan Menulis dan Kemampuan Berfikir Kritis Siswa Kelas IV SD Gugus Patimura Pada Tema Cita-citaku". E-Journal PGSD Universitas Pendidikan Ganesha, Volume 3, Nomor 1.

Sumantri, Made, dkk. 2013. "Pengaruh Model pembelajaran Inquiry Terbimbing Berbasis Kemampuan Generik Sains Terhadap Pemahaman Konsep IPA Siswa SD Kelas V di Kelurahan Banyuasri”. EJournal PGSD Universitas Pendidikan Ganesha, Volume 3, Nomor 1.

Susanto, Ahmad. 2013. Teori Belajar dan Pembelajaran di Sekolah Dasar. Jakarta: Prenada Media Group

Tegeh, I Made, dkk. 2013. "Pengaruh Pendekatan Inquiry Terbimbing Tehadap Hasil Belajar IPA Siswa Kelas V SD Gugus IV Kecamatan Sukasada

Wisudawati dan Sulistyowati. 2017. Metodologi Pembelajaran IPA. Jakarta: Bumi Aksara

Rasana,Raka. 2009. Model-model Pembelajaran. Singaraja: Universitas Pendidikan Ganesha. 